\title{
Role of the inner cell mass in controlling implantation in the mouse
}

\author{
M. H. L. Snow, J. Aitken*† and J. D. Ansell \\ M.R.C. Mammalian Development Unit, Wolfson House, 4 Stephenson Way, \\ London NWI $2 \mathrm{HE}$, and \\ *Institute of Animal Genetics, West Mains Road, Edinburgh 9, U.K.
}

\begin{abstract}
Summary. Studies with mouse blastocysts and trophoblastic vesicles showed that the inner cell mass was not essential for controlling trophoblast activity during delay of implantation.
\end{abstract}

Recent work with mouse blastocysts deprived of the inner cell mass (ICM) strongly suggests that the ICM exerts a regulative influence over the development of the trophectoderm (Gardner \& Johnson, 1972; Snow, 1973a,b, 1975; Ansell \& Snow, 1975) by inhibiting giant cell transformation and stimulating cell proliferation. During normal embryonic development the trophectoderm cells around the blastocyst cavity cease dividing and undergo giant cell transformation, becoming polyploid, whereas those cells overlying the ICM remain diploid and proliferate, thus forming the ectoplacental cone and extra-embryonic ectoderm (for review, see Gardner \& Papaioannou, 1975). In the total absence of an ICM there is no proliferation of the trophectoderm and giant cell transformation is precocious (Ansell \& Snow, 1975; Snow, 1976). Since delay of implantation of the mouse blastocyst is associated with an inhibition of giant cell transformation, it seemed possible that the suppression of trophectoderm activity during this phase was mediated via the ICM. To test this hypothesis mouse 'blastocysts' with and without an ICM were transferred to the uteri of foster mothers in delay of implantation.

Trophoblastic vesicles were produced in vitro by culture of 2-cell embryos, of the randomly bred $\mathrm{Q}$ strain of mice, with $0.05 \mu \mathrm{Ci}\left[{ }^{3} \mathrm{H}\right]$ thymidine (methyl-T-thymidine, sp. act. $17.6 \mathrm{Ci} / \mathrm{mmol}$ : Radiochemical Centre, Amersham) $/ \mathrm{ml}$. At this critical concentration of tritium the cells forming the ICM are selectively killed by the $\beta$-radiation from incorporated $\left[{ }^{3} \mathrm{H}\right]$ thymidine (Snow, 1973a,b). Vesicles and intact cultured blastocysts were subsequently transferred to pseudopregnant foster mothers $2 \frac{1}{2}$ days post coitum. At the time of transfer, the recipients were ovariectomized and upon recovery from anaesthesia were given a subcutaneous injection of $1 \mathrm{mg}$ medroxyprogesterone acetate (Provera: Upjohn) in 0.05 ml distilled water. After 4-6 days some of the animals were killed and the uterine horns removed, fixed, embedded in paraffin wax and sectioned longitudinally, while the remaining females were given a s.c. injection of $0.025 \mu \mathrm{g}$ oestradiol-17 $\beta$ (Sigma Chemicals Ltd) in $0.05 \mathrm{ml}$ arachis oil. The latter animals were killed 3 days after injection and the decidual swellings excised, fixed and examined histologically for the presence of embryonic material.

The results are summarized in Table 1. Normal blastocysts and trophoblastic vesicles appeared to enter a state of embryonic diapause when subjected to the uterine environment during delay of implantation. None of the trophoblastic vesicles observed during delay contained ICM remnants or giant cells. After injection of oestradiol-17 $\beta$, however, blastocysts and vesicles were activated, induced a decidual response in the endometrium and implanted. The implantation sites associated with the trophoblastic vesicles were indistinguishable from those described by Gardner \& Johnson (1972) and Snow (1973b), exhibiting small numbers of giant trophoblast cells and completely lacking derivatives of the ICM.

These results show that the uterine factors controlling implantation in the mouse affect the blastocyst as a whole or the trophoblast, but do not have to act via the inner cell mass.

† Present address: World Health Organization, 1211 Geneva 27, Switzerland.

\$ Present address: Department of Zoology, University of Edinburgh, West Mains Road, Edinburgh 9, U.K. 
Table 1. Implantation of mouse blastocysts and trophoblastic vesicles

\begin{tabular}{lccccc}
\hline & \multicolumn{2}{c}{ Blastocysts } & & \multicolumn{2}{c}{ Vesicles } \\
\cline { 2 - 3 } \cline { 5 - 6 } & $\begin{array}{c}\text { Without } \\
\text { oestrogen }\end{array}$ & $\begin{array}{c}\text { With } \\
\text { oestrogen }\end{array}$ & & $\begin{array}{c}\text { Without } \\
\text { oestrogen }\end{array}$ & $\begin{array}{c}\text { With } \\
\text { oestrogen }\end{array}$ \\
\hline No. of embryos transferred & 12 & 20 & & 28 & 39 \\
$\begin{array}{l}\text { No. of recipients } \\
\text { No. of recipients with embryos }\end{array}$ & 3 & 5 & & 4 & 6 \\
$\begin{array}{l}\text { No. of embryos transferred to } \\
\text { recipients with implantations }\end{array}$ & 2 & 2 & & 4 & 1 \\
No. of embryos recovered & 8 & 9 & & 28 & 7 \\
\hline
\end{tabular}

In these experiments very few trophoblastic vesicles implanted after oestrogen stimulation. This may indicate that trophectoderm viability is impaired by culture with $\left[{ }^{3} \mathrm{H}\right]$ thymidine, although such vesicles grow well in ectopic sites for at least 10 days (Snow 1973b). Another possibility is that the action of progesterone in maintaining the viability of blastocysts in delay (Weitlauf, 1971; Hensleigh \& Weitlauf, 1974) may be mediated via the ICM and in the absence of these cells the ability of the trophoblast to initiate implantation declines more rapidly.

\section{References}

ANSELL, J.D. \& SNow, M.H.L. (1975) The development of trophoblast in vitro from blastocysts containing varying amounts of inner cell mass. J. Embryol. exp. Morph. 33, 177-185.

GARDNER, R.L. \& JOHNSON, M. (1972) An investigation of inner cell mass and trophoblast tissues following their isolation from mouse blastocysts. J. Embryol. exp. Morph. 28, 279-312.

Gardner, R.L. \& Papaloannou, V.E. (1975) Differentiation in the trophectoderm and inner cell mass. In The Early Development of Mammals, pp. 107-132. Eds M. Balls \& A.E. Wild. Cambridge University Press.

Hensleigh, H.C. \& Weitlaup, H.M. (1974) Effect of delayed implantation on dry weight and lipid content of mouse blastocysts. Biol. Reprod. 10, 315-320.

SNow, M.H.L. (1973a) Abnormal development of preimplantation mouse embryos grown in vitro with $\left[{ }^{3} \mathrm{H}\right]$ thymidine. J. Embryol. exp. Morph. 29, 601-615.

SNOw, M.H.L. (1973b) The differential effect of $\left[{ }^{3} \mathrm{H}\right]-$ thymidine upon two populations of cells in preimplantation mouse embryos. In The Cell Cycle in Development and Differentiation, pp. 311-424. Eds M. Balls \& F.S. Billett. Cambridge University Press. SNOW, M.H.L. (1975) The functional competence of the inner cell mass. In New Approaches to the Evaluation of Abnormal Embryonic Development, pp. 394-407. Eds D. Neubert \& H.J. Merker. Georg. Thieme Publishers, Stuttgart.

SNOw, M.H.L. (1976) The immediate postimplantation development of tetraploid mouse blastocysts. $J$. Embryol. exp. Morph. 35, 81-86.

WeitLAUY, H.M. (1971) Effect of progesterone on survival of blastocysts in uteri of ovariectomized mice. J. Endocr. 51, 375-380.

Received 29 April 197 